Article

\title{
Holy Dung: Comic Signs of Consubstantiality in Martin Luther Films
}

\author{
Terry Lindvall * and Morgan Stroyeck \\ Communication and Christian Thought, Virginia Wesleyan College, 1584 Wesleyan Drive, Norfolk, VA 23502, \\ USA; mcstroyeck@vwc.edu \\ * Correspondence: tlindvall@vwc.edu; Tel.: +1-757-631-1012 \\ Academic Editor: Joseph Kickasola \\ Received: 26 October 2015; Accepted: 14 February 2016; Published: 26 February 2016
}

\begin{abstract}
One problem with the religious sub-genre of Hagiographic films is that they frequently romanticize, sentimentalize, or idealize the lives of saints. Our purpose is to excavate three major film biopics on the life of Protestant reformer Martin Luther and demonstrate where the use of excremental humor humanizes him. Such coarse embodied humor invites a consubstantial identity of a holy man with his secular audience. Where laughter is present, saints are not elevated to being "more spiritual than God." The use of excremental humor gives weight, or the gravity of earth, to the transcendent, bringing the holy down into the everyday. We argue that it is the comedy in the life of Luther that makes him more authentic, showing how film can communicate the presence of God in earthen vessels.
\end{abstract}

Keywords: Luther; consubstantiality; laughter; comic; humor; hagiography; body; vulgarity; dung; film

\section{Introduction}

"God walks about in a mask, as at Mardi Gras." ([1], p. 204)

At the end of director Roberto Rosselini's classic The Flowers of St. Francis (1950), the saint dismisses the little brothers to follow their calling. They want to know which way to go. Where is God leading them? St. Francis orders them to stand in a circle and spin around in circles until they fall down from dizziness. The direction toward which their heads point is the path for each of them. God's Providence has been made known by the comedy of their falling bodies.

The conception of "spiritual senses" can assume a high, lofty, and romantic tone while forgetting its vulgar, corporeal base. However, the arts can offer visceral experiences that function as hints, clues, and rumors of the Divine [2]. Works of art can evoke a poetics of everyday experience or communicate the wonders of a sacramental world. However, take William Blake's expression of hope: To see a World in a Grain of SandAnd a Heaven in a Wild FlowerHold Infinity in the palm of your handAnd Eternity in an hour

This hope stems from an augury of innocence. Real experience provides connection with a different lived response in the recognition of how an aesthetic moment can open up more convincing evidence of embodiment: namely, reminders of this sack of worms, dung, and our decaying bodies.

If the poetics of cinema can spark a theologically significant awareness, a taste of transcendence, sacrament, ritual, or grace, it may also do so at the most basic level, the level that all men and women have in common, namely the level of the truly vulgar. As with St. Jerome's translation of the Vulgate- - the Word of God transposed into the common, vernacular language — so the lives and words 
of saints on film must be translated into images that are recognizable. However, hagiographic films rarely take us there, often because of an excess of hyper-spirituality and a lack of human laughter.

The key to the failure of hagiographic films is that they ignore this basic truth. They aspire to be otherworldly religious icons, exploring how God crowns men and women with glory, without wondering how we are bathed and baptized in human folly. It is the body that not only grants gravity to the spirit, keeping it tethered to the earth, but also splashes comedy into the whole human drama.

For Kenneth's Burke's rhetoric, "signs of consubstantiality" indicate the kinds of identification that occurred with symbolic messages, both verbal and visual. Effective rhetorical persuasion depended upon these signs that would make the audience or spectator one with the message. Celluloid images of saints seek to elicit responses of piety and awe of these chosen ones who rise above their stations in life. However, few of these images actually give ordinary people the taste of holiness, and the reason for this is that they do not give us the sensory experience of being fully human.

Consubstantiality is essential in a poetics of theology ${ }^{1}$. As Burke defined it, "A is not identical with his colleague, B. But insofar as their interests are joined, A is identified with B. Or he may identify himself with $B$ even when their interests are not joined, if he assumes that they are, or is persuaded to believe so" ([3], p. 20). Even though persons remain unique, one can become "substantially one" with another. The art of rhetoric can transform the difference with others into acts of identification. The gap between spectator and images of holiness is one in which holiness is constructed as radically different from human experience and "stigmatized" as too different or unconnected. Thus, how does one establish a rapport with audiences that find the spiritual experience too foreign?

One means of persuasion in film is to tap into the shared human experience of the ordinary. Our investigation into the hagiographic films of Martin Luther led us to ask whether such signs of consubstantiality existed in the cinematic texts as they do in his coarse and satiric writings. We argue that one of the signs of transcendence that lay embedded in the best religious films is in the experience of laughter, particularly in its manifestations in scatology as it was communicated through the vivid writings and table talk of the German Reformer. After a brief excursion into biographical details, we wanted to examine three films that present the man as the chief Protestant "saint" to see if they offer any evocative aesthetic experiences, if they might make us laugh and cringe as do his writings.

Burke, again, argued that one can persuade a man only insofar as you can talk his language by speech, gesture, tonality, order, image, attitude, idea, identifying your way with his ([3], p. 55). If one is to have a visceral response to films, beyond the visual and aural, one may find that certain images can evoke repulsion and comedy, almost simultaneously, that reverberates in the body [2].2

Gavrilyuk and Coakley argued convincingly for recognition of how sensory language has been used to express encounters with God. From the Hebrew summons to "taste and see that the Lord is good," (Psalm 34:9) to the Apostle Paul's affirmation that the faithful will "behold the glory of the Lord as in a mirror" (2 Corinthians 2:18), their umbrella concept of "spiritual senses" covered a "variety of overlapping, yet distinct, expressions in which 'sense' in general or a particular sensory modality (vision, audition, olfaction, touch or taste), is typically qualified by reference to spirit" ([4], p. 2). The phenomenal experience may be as intense as the ecstasy of St. Theresa of Avila or as humdrum as the details from the Diary of the Country Priest, as vivid as a burning bush or as indirect as Flannery O'Connor's warthog from hell. This is not to say that God could be perceived directly through the human senses. Except for the orthodox Christian standpoint regarding the life of Jesus in the first century, one has not seen God in the flesh; yet our language remains partly figurative and partly

1 On his faux news show on Comedy Central, erstwhile Roman Catholic prophet and pundit Stephen Colbert still speaks truth with his Kierkegaardian ironic voices. One cannot always tell what he really believes, but one recognizes the issues he raises. In a segment entitled "Yahweh or No Way," Colbert remonstrated against the change in the Eucharistic Mass from "being one with" to being consubstantial. "Consubstantial! What the hell does that mean?" he protested, "We're trying to get into Heaven; not take the SATs."

2 Whether disgust within the films of Peter Greenaway or the cinematic forms of grief, embarrassment, sympathy, sickness, or joy, the cinema offers lived moments, or what scholar Sara Ahmed terms as "Affective Economies." See [2]. 
literal in modes of expression that chronicle our experiences with God through the world, its people, and its arts.

Cinematic hagiography tends to romanticize, sentimentalize, or deconstruct the lives of saints. No matter how heroic (Romero) or humble (St. Francis), the religious biopic tends toward elevating the person into canonization. Films frequently end with an apotheosis of the saint. They often make the saints more spiritual than God, otherworldly and prematurely sanctified. When the principled St. Thomas More in A Man for All Seasons stands as a noble spokesman against the conniving King Henry VIII, his own coarse humor is not represented as clearly as his acts of conscience. However, he was a man for all seasons, especially in his descriptions of Luther's beshitting and being beshitted.

The use of excremental humor to give weight, or gravity, to the transcendent, bringing the holy down into the everyday, has been mostly used in comedy. Filmmakers Monty Python and Kevin Smith both employed such tactics, whether intentional or not, to emphasize the Incarnation over gnostic tendencies. The Body of Jesus Christ is, after all, a body. The One Who shared in all things with humanity, also shared the blessed dual humiliations of digestion and defecation. It may be unseemly, vulgar, or common to suggest that, but it is also orthodox. The Spirit of God breathed into humus, into earth, to make the human. It was God Who first established that amazing oxymoron, a spiritual animal. This Divine incongruity forms the foundation of a theology of comedy, the juxtaposition of two unlikely elements. Neither spiritual angels nor physical dogs laugh, Lewis reminds us. It is only the creature created in God's image that gives rise to mirth.

These bodily functions were more properly acknowledged, and one might even say celebrated, during the late medieval and early reformation periods. What Mikhail Bakhtin called the culture of carnival, with its grotesqueness and universality, made the community one, especially in its honoring of the lower bodily strata. It was as if Paul's admonition that the unseemly members receiving honor would be taken to its extreme, with all the comic absurdity ${ }^{3}$.

The turn to sensory cultural studies augurs a focus on the materiality of things, of encountering bushes and bread as spiritual experiences. How can the imperceptible be received? Can the divine be translated through the media? If one accepts that piety can be received through icons, cannot the art of kinetic icons capture something of lived experience as well? Cannot the movies, even bad religious ones, capture a hint or rumor of the Divine in such a material form? Or is this emphasis upon the flesh a return to idolatry of the basest kind? One recognizes how close the Incarnation is to a celebration of Carnival.

The task is to find a conception of catholic spirituality in the mediated representation of the lived experience of the Reformer himself. What aspects of Luther come through the films that invite a common experience? We investigate three films to discern how film can give us an experience that is theologically orthodox, particularly in their use of humor and laughter. In other words, we believe that theological ideas can and will be present, but the question here is on how these ideas are made flesh [5].

The connection of the uncouth parts of our bodies offers a comic poetry, more in the tradition of a Rabelais than a Coleridge or Wordsworth. Rather than the austere Protestant John Bunyan, the earthy Roman Catholic Geoffrey Chaucer will be our guide. ${ }^{4}$ While truth may be beautiful to behold, it is also comically rude and indecorous. Something in the fallen nature of beauty will arrest our attention and bring us to laughter. We believe that something to be shit and that shit reminds us of our own righteousness, or more precisely lack of righteousness, before the Almighty.

3 In film we see and hear, priority is given to these two sensory modalities (although the Smell-O-Vision developed by Hans Laube for William Castle's Sense of Mystery in 1960—with aromas of oranges or pipe tobacco-and director John Waters' 1982 film Polyester in Odorama with "scratch and sniff" cards—from roses and pizza to flatulence-did give it an old college try to stimulate the olfactory. However, comedian Henny Youngman conceded, "I didn't understand the picture; I had a cold.").

4 We would argue that Pieter Bruegel offers an early exemplar of this comic theology (see [6] and [7]). 


\section{The Human Luther}

One might assume that the German monk, the founder of a global denomination and an historical heroic figure as a national myth of Germany, would speak in stentorian tones, think boldly, and protest with stern propriety against the sale of indulgences, the marketing of relics, and other corrupt practices in the established Roman Catholic Church of the early 16th century. However, Martin Luther was no mere man of the mind, but a man of the bowels as well.

All was not clean and tidy as Luther was notorious for his scatological humor ([8], p. 3). ${ }^{5}$ Cursed with a bit of constipation, he would spend time in the outhouse, thinking and reflecting on what and how to say what he wanted. His world was packed down with words like Scheisse (shit), Mist (manure), Dreck (dirt/shit) and Arsch (ass). Luther wrote with uninhibited panache, offering fecal tirades against the pope as his being the "cuckoo, who devours the church's eggs and then craps out cardinals" ([9], pp. 109-17). He proposed that "out of a desperate ass never comes a cheerful fart" ([10], p. 114). ${ }^{6}$ Most importantly, however, when he recognized that the Pope and his minions were attending too closely to his every movement, so to speak, he boasted that "when I fart in Wittenberg, the Pope in Rome wrinkles his nose." One letter went as follows:

Most Hellish Father, Gently, clear Pauli, dear donkey, don't dance around! Oh, dearest little ass-pope, don't dance around-dearest, dearest little donkey, don't do it. For the ice is very solidly frozen this year because there was no wind-you might fall and break a leg. If a fart should escape you while you were falling, the whole world would laugh at you and say, "ugh, the devil! How the ass pope has befouled himself!" And that would be a great crime of lese majesty against the Holy See in Rome, which no letters of indulgence or papal prerogatives could forgive. ([13], p. 280).

His wrestling was not only against flesh and blood down in Rome, but against spiritual powers and principalities. He believed that "The devil has sworn to kill me; this I certainly know, and he will have no peace until he has devoured me. All right, if he devours me, he shall devour a laxative (God willing) which will make his bowels and anus too tight for him." Like his noble Roman Catholic counterpart, Thomas More, he viewed the Devil as his prime Accuser and a proud spirit that could "not endure to be mocked" ([13], p. 94). So mocked him he did: "But I resist the devil, and often it is with a fart that I chase him away. When he tempts me with silly sins, I say, 'Devil, yesterday I broke wind too. Have you written it down on your list?'" ([13], p. 74). He also emphasized his own humble humanity when he referred to his own death in vulgar terms: "I'm like a ripe stool and the world is like a gigantic anus, and so we're about to let go of each other" ([14], pp. 177-80). His more reasonable colleague Philipp Melanchthon once acknowledged that "occasionally Luther's rough and coarse way of writing had often offended friends and foes alike."

Eric W. Gritsch argues that Luther's earthiness was part of his theology, pointing out that "the promise of Christ's imminent return made Luther serene and saved him from being dead serious about his own self." His early life of failed piety, self-recrimination, and guilt led to wrestling with his faith, until reading the Scriptures, he became convinced that one was "justified by faith" and not through one's own righteousness or strength. Grace invaded one's life and shined a light on the "dung" of self-righteousness.

Luther employed both humor and satire to proclaim his biblical discovery and to ridicule those powers of darkness that would assault him. However, as Gritsch points out, his humor "tended toward the scatological. He claimed he experienced a spiritual revelation while on the toilet: "The Holy Spirit

5 Diamaid MacCullough's Reformation: A History starts with a wonderfully vivid description of a gargoyle's buttocks to introduce the changes occurring during this tumultuous and hilarious era [9].

6 One 16th century Apostle of Rome saint called a "mystic in motley," Philip Neri, did practice cheerfulness, believing a good-humored attitude to be more Christian than a melancholy one. As he quipped, "A joyful heart is more easily made perfect than a downcast one" (see [11] and [12]). 
unveiled the Scriptures for me in the tower.' The pope, a nemesis, was his 'dearest little ass-pope.'” Such moments, Gritsch argues, deserve "to be integrated into his legacy." Not only did such humor attest to his faith that all would be well at the Second advent of Christ, but that this life in a decaying body was not only a source or grief and pain, but also of a wild incongruity of humor [12].

Biographers show Luther as something of the country boy marveling at the city slickers of Italy, as Germans were "simple folk" and Italians had fasts that were "more splendid than our great banquets. They adorn themselves sumptuously. Where we spend a gulden for satin, they need ten. Their chastity is sodomy, as they themselves declare. Betrayed by a perverse intelligence, they do violence to natural and divine law by despotically forbidding matrimony. I guess they'll ban shitting next." Mocking the Lateran Council of 1515, Luther quipped, here they decreed it permissible to believe in the resurrection of the dead, and for each cardinal to have five boys for his Ganymedes. But Leo took that back" ([12], pp. 21-22).

When Luther discovered that Cardinal Albert of Mainz, who had to sell indulgences to pay for his loan to the Fuggers Bank for his pallium in the see of Mainz (and would subsequently commission the infamous Johan Tetzel to sell indulgences on his behalf), had set some relics on display, Luther found a ripe opportunity to display his own gifts of satire. Publishing a little travesty entitled "News from the Rhine," he lampooned possible antiquities with a detached sardonic tone: "three flames from the burning bush upon Mount Sinai; two feathers and one egg from the Holy ghost, One full pound of the wind that passed by Samuel in the cave on Mount Sinai. Three lovely locks of Absalom's hair, by which his head caught hold of the oak" ([12], p. 116).

Examining his own sins, he confessed to wrath, of which he easily convicted himself. Avarice did not trouble him (he had enough money; neither did lust, as he could impishly look at Kate, "I get plenty of what it takes to remedy that. But wrath just won't turn me loose. Why, I sometimes rage about a piddling thing not worthy to mention," ([12], p. 149)). However, with the devil as a literary device, his self-accusations could take on the structure of a cross-examination. The Devil would challenge him, "Tell me, my friend, where do you find that in the bible? Where did God teach or command it? If it is only man who teaches it, without God's word, then it is all a lie, and you are just tomcatting around in the name of the church" ([12], p. 119). ${ }^{7}$

\section{Sensing the Divine from the Outhouse}

When a friend, John Schlaginhauffen, felt the weight of self-incrimination and self-reproach, Luther moved him to laughter with his musings on the devil, for when he would come "at night to worry me, this is what I say to him: 'Devil, I have to sleep now. That is God's commandment, for us to work by day and sleep at night.' If he keeps on nagging me and trots out my sins, then I answer, "'Sweet devil, I know the whole list. Also write on it that I have shit in my breeches. Then hang that around your neck and wipe your mouth on it" ([12], p. 191). Whenever the Devil used scripture against him in a debate on the law or sin, Luther conceded to the devil's arguments, due primarily, as Luther pointed out, that he himself was a sinner, but when the argument turned on the gospel, the enemy was easily vanquished. When the devils that pestered him at night could not get to his heart, they grabbed his head and made it ache: "When I can't take it any longer, I am going to stick them up my ass. That's where he belongs" ([12], pp. 191, 194). As Gritsch pointed out,

Coarse language in treating of and with the devil was an appropriate way of showing contempt for doubt and despair. It also produced good humor, that most effective means for warding them off. He like to tell of the lady in Magdeburg who, when approached by a

7 In one bit of his Paralipomena, Luther penned "I wrote it after dining—but a Christian can speak better inebriated than a papist can sober." 
ghoul, let a fart out of her bed and said, 'There you have a staff. Use it for a pilgrimage to your idol in Rome. ([12], p. 195). ${ }^{8}$

For Luther, the devils could not bear such ridicule and contempt. "If we once recognize Satan to be Satan, why, then it is easy enough to confound his pride by saying, 'Kiss my ass,' or 'Shit in your pants and hang them around your neck.'" ([15], p. 286). Again, Christ's strength was made perfect in his weakness. British author C. S. Lewis would echo this principle in his prologue on The Screwtape Letters, saying the "best way to drive out the devil, if he will not yield to texts of Scripture, is to jeer and flout him, for he cannot bear scorn." ([16], p. 5). Lewis justified this tactic by grounding it in the animal nature of human beings.

The coarse joke proclaims that we have here an animal which finds its own animality either objectionable or funny. Unless there had been a quarrel between the spirit and the organism, I do not see how this could be: It is the very mark of the two not being "at home" together. ${ }^{9}$ ([17], p. 133).

One of Luther's besetting and troubling conditions was his constipation. He spent many an hour in his lavatories. His presence there not only gave him time to reflect and remonstrate, but gave him metaphors for his theology and epithets for his enemies. Along with Rabelais, he would mark the era as one that combined the spirit and the flesh, in all their weaknesses, to offer a sensual life that walked toward God. This was no Platonic musing in a cave of illusions, but plenty of the reality of his own body and its weaknesses.

Few dispute the vulgar expressions of Luther the man. While some perceptions of Luther have been filtered through the lens of psychiatrist Erik Erikson's Young Man Luther, particularly as adapted to John Osborne's play (and the subsequent film), Luther remains a complex, sensual man. That he wrestled with his devils and his lack of sanctity is renowned, but he was straightforward with his thoughts. He argued that if we do not have God's word, we will "believe anything. Without it, there is nothing so absurd we won't fall down and worship it, just as the Romans worshipped Priapus" ([1], p. 46).

\section{World of Shadows, World of Sunlight}

The senses can perceive clues of the Divine in both darkness and light. Famously, Ingmar Bergman's knight Antonius Block in The Seventh Seal [18] sought God through a young girl accused of being in league with the devil. He had tasted a symbolic Eucharist in a meal of strawberries and cream, but his inquiry into the diabolical association of the alleged witch troubled him more deeply.

However, for Luther, it was beneath the sun's rays where the nature of a thing, its true quality, became manifest at last where one saw "wax grow soft and dung get hard" ([1], p. 21).

Visual media has shaped the multifaceted image of Martin Luther, particularly feature films. The three we selected were duly consulted with theologians and experts. Luther's image in previous engravings and writings covered a broad scope, with the spectrum ranging from him being the great prophet and third Elijah, a herald of peace and father of the Church, the revived Cicero and father of the Reformation to the "mad dog, grim bear, Devil's apprentice" of the 16th century. ${ }^{10}$ In her study of Luther, Esther P. Wipfler also points to the punning caricature of Luther as Luder (a rascal or scoundrel)

8 Luther also recommended "songs for driving the devils away. I really like it when we sing loudly in church." When the word was made flesh and put into song, the devil cannot bear to hear the good news. "He has to get several miles away."

9 Lewis noted that it was difficult to "imagine such a state of affairs as original- to suppose a creature which from the very first was half shocked and half tickled to death at the mere fact of being the creature it is. I do not perceive that dogs see anything funny about being dogs: I suspect that angels see nothing funny about being angels."

10 Two of the images Elijah and Cicero hint at the subterranean presence of satire and humor in the life of Luther. Elijah's battle with the prophets of Baal and his daring mocking of the pagan god, (e.g., "Is he on vacation? Is he out relieving himself?"), parallel Luther's own ridicule of a corrupt 16th century Papacy. Cicero, the great Roman orator, spent much time discussing the role of humor in polemical discourse, accused of exceeding his contemporaries' sense of propriety with excessive jocularity. 
or Septiceps (the seven-headed dragon of the apocalypse [19]). Anti-Luther woodcuts show him as listening to the whispers of the Devil or being played like a bagpipe by the Prince of Darkness.

In the various commemorations of the reformer, as Protestant hagiographies, one treads solemnly. ${ }^{11}$ With official theologians serving as consultants, one expects sobriety and propriety in its utmost. Talk as much as disputations characterized the life of Luther. Humor made the German hero human. However, in the 1953 film Martin Luther, one of his colleagues looks at him and barks, "Come on Martin, don't be so serious." Known for an earthy, even vulgar, sense of humor, the question arises: how have films about the German reformer bowdlerized or sanitized or neglected his rollicking wit? In his vulgar and satiric exchanges with Sir Thomas More, the witty man for all seasons, and with Erasmus, the husband of Dame Folly, Luther exhibited more than a passionate desire for reform.

A silent film biography presented seriously as having educational value was released in 1911. Doktor Martinus Luther put forth the basic facts with a bit of a romantic love story with Katharina. With more promise, in 1913, Luther was portrayed as a wandering goliard type earning his livelihood singing at courts.

Director Karl Wüstenhagen's 1923 Martin Luther: His Life and Time [20] starred the director as the titular hero and offers a lively biographical portrait of the rotund reformer. Shot in Wittenberg, Erfurt, and Wartburg, it allows Luther to be delightfully human. "After a comical song on marriage is sung by a rousing chorus," (sic. in a silent film!), a Papal Nuncio delivers Pope Leo X's Exsurge Domine, the bull of excommunication. After reading it with his friends, Luther "bursts out laughing," with an intertitle proclaiming: "So, to it, students. Set to work! Quickly fan the flames for me." Luther's hearty humor dominates the scene, even as he declares: "Because you have destroyed Christ, may the everlasting fire consume you." With panache and a histrionic gesture, Luther heaves the certificate into the flames. His reformation then spreads like wildfire until it all ends showing Luther with his family sitting around a Christmas table, suggesting more of a nationalistic thrust akin to Bismarck's Kulturkampf than true reform ([19], p. 28). ${ }^{12}$ The film offers Luther as an enlightened redeemer of sorts, heralding a parallel between the German's biography and the Life of Christ. He first appears standing in shadows beneath Gothic arches, light shining down on him from above, in an overblown allusion to John 12:46, "I am come a light into the world, that whosoever believeth in me, should not abide in darkness" ([1], p. 40). Indulgence salesman Johan Tetzel's character is portrayed as part demagogue and as Luther's vernacular foe "in the street." The carnivalesque trading of indulgences is 'exaggerated in risible ways." In spite of its jingoistic propaganda, the film inserts jocular bits.

In contrast, director Irving Pichel's biographical Luther (1953) [21] aimed at hagiography at its most solemn, even with a very garrulous protagonist. Nominated for two Academy Awards and lauded by the National Board of Review (as the fourth best film of the year), it had been researched by distinguished Lutheran theologians like Jaroslav Pelikan. The film's subtext also raised themes of spiritual freedom in the era of communism and the Cold War. Like Cecil B. DeMille's The Ten Commandments (1956), freedom, rather than grace, looms as the chief theological concern. In its quest for authenticity, the distinguished British actor Niall McGinnis was chosen because he looked "like Luther" ([19], p. 111).

Supported by the majestic strains, however anachronistically, of "A Mighty Fortress is Our God," the narrator John Wiggin invites spectators into 1505, opening with images of Gothic arches and God's implacable fires, amidst the dread and torments of death, judgment and hell. Sixteenth century Christendom is portrayed as mixed with paganism through the selling of indulgences, where coins are

11 Unlike Luther, dramatic films have not showcased Calvin or Zwingli, the former for good reason as academic, lean, serious French/Swiss lawyers are very dull. One finds little drama with Calvin except for the execution of Severus, the Unitarian. Laughter is nonexistent. Zwingli, however, could be the subject of a merry slapstick comedy. One does find gallows jokes such as "How many Unitarians did Calvin execute?" to which the answer given is "not enough."

12 In the 1927 film, when told to burn Luther's writings, the inter-title announces that instead the papal writings would burn, asserting that "If the Pope writes with a Latin goose quill, our Luther will answer with a German eagle plume." 
squeezed out of a gullible and superstitious populace. It is a time where the church has "forgotten the mercies of God" and replaced them with implacable judgments.

Switching to a scene in a Gasthaus tavern, hearty German men sit around singing and drinking, toasting their host, an angst-ridden Luther who confesses that he was not made for the law profession. One of his compatriots taunts him with "Come on Martin, don't be so serious." Martin gives away his law books and his lute and ekes out some dark quip: "The last thing I want to be is a Skeleton at my own feast."

The heaviness of his life appears in his submission to the discipline of his Augustinian order, where he feels he must renounce the flesh, mortify and deny it, and suffer. Bound to his vows, Luther obsesses over his lack of righteousness, enduring endless acts of penance, with no peace. Whips line the wall, suggesting his physical self-mortification. Looking for a loving Father, he only sees an angry Judge, so much so that he quakes at the Eucharistic Mass. Sent to Rome, he perseveres through laborious prayer on each step of his ascent in the holy city. Ascetic piety does not bring relief.

When laughter occurs, it is purposeful. Asked what would happen if the Word could be read by every farm boy or swine girl, with each interpreting it in his or her own way, Luther laughs and says, "Why then, we'd have more Christians." When the secretary of Elector Frederick, Duke of Saxony, informs him that the Duke is looking for new professors for his little University in Wittenberg, Luther ejaculates a hearty "hah!"

His ire is provoked when a priest brings such relics as four fragments of St. Jerome, two of St. Chrysostom, and a morsel of bread eaten at Last Supper, which he promises will reduce the buyer's torment in Purgatory by 1,200,202 years. In such a display of useless relics, Luther protests and when asked whether he might end up preaching himself out of his pulpit, his university and his Church, he exclaims "nonsense!" with a laugh. However, he raises questions about their efficacy and posting his notices for debate, in 95 theses, on the door of the Wittenberg Cathedral, he poses the question, if the Pope has the authority to empty Purgatory, why does he not do it for free? The response from the Papal headquarters is not unexpected: "What drunken monk wrote this?"

The narrative remains quite sober, with an image of a martyred John Hus, the "burning goose," on an engraving. Like the false offer of Schutzbrief given to Hus, Luther is also offered safe conduct for a debate in Leipzig with Johann Eck. When they do debate, Eck accuses him of being another Husite, "Heresy, Dr. Luther, Heresy!" to which Luther retorts, "So be it! It is still the truth!"

However, as young iconoclasts start breaking church windows, Luther finds himself praying "Lord deliver me from my enemies and my friends." His dramatic stance at the Diet of Worms finds him forceful, determined, adamant, wise, and prayerfully seeking the right words to say. When confronted with the church's teaching, he caustically responds: "I know what's in the book of Catechism, do you?"

The remainder of the film follows Luther's kidnapping, his rescue of the nuns, including the quietly subversive Kate, Erasmus' trivial attacks on the bellies of the monks, and his translation of the New Testament into German, showing that "a German lark can sing as sweetly as any Greek or Latin nightingale." With Luther receiving the Augsburg Confession, his people join in cheering their leader by singing his Ein' Feste Burg in closing, still in the anachronistic isometric form.

Twenty years later in 1973, playwright John Osborne's controversial play on Luther (1961) was adapted for the screen by the American Film Theatre as a stylized, somewhat documentary and very stagy movie directed by Guy Green. Actor Stacy Keach portrays brooding German with the charming Judy Dench as Katharina von Bora.

One gets a sense of Osborne's gravitas and angst from his previous work as Look Back with Anger in the first act of his play; however, by the second Act, we see more of the Osborne who scripted Tom Jones, even sharing the comic character actor Hugh Griffith as Johann Tetzel. Theatre critic Michael Feingold of the Village Voice lauded its explicitness of language and details as remarkable for an historical character movie, particularly one on such a revered religious figure. 
In the prologue, an angry, disappointed knight, who has seen the slaughter in the wake of the Peasants' Revolt, caustically barks at Luther, accusing him for the blood of the people and calling him a butcher. His ironic greeting sets a disturbing tone for the angst-ridden Martin.

Germany is carpeted with monks, says the condescending knight. For Luther, it is a mortification of the flesh with ascetic self-chastisement. Watching the first Act is like wearing a hair shirt for hours. Kenneth Tynan, drama critic, found the language urgent and sinewy, with "images that derive from bone, blood, and marrow."

The first truly comic moment occurs with the monks confessing their sins. In contrast to Luther's anguished soul-searching, the brothers spit out petty and trivial offenses. One confesses to failing to arise quickly from his bed; another sloth where he omitted to shave and to vanity believing his skin fairer than that of his brothers; another forgot to have a candle ready for Mass; another taking a bath allegedly for his health, when actually as his body was lowered into the tub, he realized it was an inordinate desire as it was his soul that was soiled. One looked repeatedly at a woman who dropped alms in his bag.

Luther's grievous confessions center on being the Devil's worm bag. He is told: "Let Brother Martin remember all the degrees of humility; and let him go on cleaning the latrines." The comedy arises as Luther is ironically constipated. He is sent where he needs to go.

Luther's confessions, somewhat more strained and severe and yet as ridiculous, are that he transferred fits of worry from his mind to his bowels. Brother Weinand later mocks Luther, suggesting that every time "you break wind, they say you rush to a confessor." "It's their favorite joke" of you. Brother Weinand confides to Luther that he was sweating like a pig in a butcher's shop. You know what they say, don't you? Wherever you find a melancholy person, there you'll find a bath running for the devil." Such was the wisdom of Evagrius, who included sadness as one of the eight deadly vices and hilaritas as its corresponding virtue. Weinand has him repeat the Apostle's Creed, reiterating the phrase "I believe ... in the forgiveness of sins." He grunts, "I wish my bowels would open. I'm blocked up like an old crypt."

After his first Mass, his father laughs, as much from nervousness as from relief. Hans Luther jokes that the tonsured order of Augustinian Order of Eremites at Erfurt (1506) are like eggs with a beard; he hopes to get his donation of 20 guilders worth of food and drink in the celebration of his son's first Eucharist. He sees his son as too pale and worried, quipping, "Brother Lazarus they ought to call you." Drinking too much wine ("convent piss") Hans embarrasses his son by telling all the monks what people say: "Bread thou art and wine thou art; and always shall remain so." The mocking of transubstantiation disturbs the other monks who leave.

The comic face of Dominican John Tetzel (with the wide eyes, bulbous nose, and burley eyebrows of Hugh Griffith), sub-commissioner to the Archbishop of Mainz, shouts out "any sick idiot here who hasn't heard of me?" Hawking his wares like a carnival barker, "What I bring you is indulgences. Don't hold back!" and "the soul flies out of Purgatory and sings. Come on then, get your money out." Ostensibly, the money is to go to restore the ruined church of St. Peter and St. Paul in Rome, which contain the bodies not only of the holy apostles Peter and Paul, but of a hundred thousand martyrs and no less than forty-six popes! To say nothing of the relics like St. Veronica's handkerchief, the burning bush of Moses, and the very rope with which Judas Iscariot hanged himself!

For as little as one quarter of a florin, my friend, buy yourself one of these letters. And for your dead relatives too, no need to repent. For remember: As soon as your money rattles in the box and the cash bell rings, then the soul flies out of purgatory and sings. So, come on then! Get our money out!"

Martin is, of course, outraged of this mockery of the holy orders.

Discussing the issue with his superior, Johann von Staupitz, Vicar General of the Augustinian Order, Luther quotes Paul's letter to the Colossians 3:3 ("Are you so foolish, that ye have begun in the spirit, you would now end in the flesh?") as an allegory of going to the lavatory. "If ever a man could 
get to heaven through monkery, that man would be me." It is a phrase echoed by Erasmus in his In Praise of Folly. However, he complained that "people like Erasmus get upset because I talk of pigs and Christ in the same breath."

Like Jesus' exposure of the hypocrisy of lawyers and Pharisees, Luther's challenge strips the religious authorities and makes them ridiculous. He does step on toes of his protector, the Duke, with his mocking reference to such holy relics as the feather from the wing of the angel Gabriel, but Frederick had already invested too much in his professor. Luther laughingly points out that while Christ had twelve apostles, one could find holy relics of 18 apostles buried in Germany alone.

The film jauntily focuses on Luther's constipation: Staupitz demands he do "something about those [damned] bowels," to which Luther offers the famous quip: "Who knows if I break wind in Wittenberg, they may smell it in Rome."

Luther delivers his sermon at Castle Church, Wittenberg, on 31 October 1517, on the Eve of All Souls' Day, where he satirically mocks those seeking shells and trinkets: people will "mumble for magic with lighted candles to St. Anthony for your erysipelas [skin rash also known as St. Anthony's fire] ... to St. Apollonia if you've got the toothache, and to St. Louis to stop your beer from going sour." Tomorrow, he suggests, you'll queue for hours so that you can get a "cheap-rate glimpse of St. Jerome's tooth ... or the remains of the loaf at the Last Supper."

He minces no words for those scholastics who practice casuistry, by calling reason the devil's whore and Aristotle a stinking goat. He bids them "come to me ... in toilet," where the Righteous shall live by faith and his bowels can be flushed. Tetzel gossips by accusing Luther as saying that the religious men in Italy lift their legs on street corners like dogs. Cajetan retorts, "I hope he didn't see any cardinals at it. Knowing some of them as I do, it's not impossible. Well, let's have a look at this foul-mouthed monk of yours" ([22], p. 83). ${ }^{13}$

Such monk appears at the Elster Gate, with fire blazing, declaring that he had been "served with a piece of paper (papal bull), that came from a latrine called Rome." Luther ends with his classic aphorism: "Papal decretals are the devil's excretals!"([22], p. 97). Now, he promises, this "Bull is going to roast and so are the balls of the Medici!"

By the end of the film, Luther's courage at the Diet of Worms against Eck is played out solemnly and politically, ending with "Here I stand; God help me. I can do no more. Amen." Yet, the play continues on with Martin and his Katie and their baby son, as he lightly notes, "It's a shame everyone can't marry a nun."

Because of Luther's fame and notoriety, Staupitz observes that "Every time you belch now, the world stops what it is doing and listens." Luther simply belches and returns to his child Hans. He speaks softly, summing up his own trajectory from angst to faith: "What was the matter? Was it the devil bothering you? Um. Was he? Old Nick? Up you, old Nick. Well don't worry. One day you might even be glad of him. So long as you can show him your little backside. That's right, show him your backside and let him have it."

Luther's coarse humor triumphs, even if softened by the sweet presence of a child. His humanity is completed, a saint with bowel problems and the need for a muzzle on his mouth. It is the comedy, however, which humanizes him in Osborne's script and allows him to become consubstantial with his viewers. The vernacular German, along with the wooing and wedding and kissing of Kate, connects to the vulgar spectator.

\section{Hollywood's Luther}

Whereas Irving Pichel's Luther offers solemn hagiography and John Osborne's play gives a glimpse of Luther's vibrant human vulgarity, Eric Till's Luther (2003) [23] shows the ebullient reformer in a more saintly, heroic, and, consequently, distant style. The film thrusts the viewer into the struggle of young

13 The film edited out, and essentially bowdlerized, the third scene of Act 2, with no reference to a dog returning to its vomit. 
monk Luther, after he prays to St. Catherine, and continues on a jaunty ride through Luther's struggles with faith, German politics, and the Catholic Church's corrupted teachings. Unfortunately, the lush, close-up focused film brings with it a similarly small-angled view of Luther's theological writings and arguments, and any substantial religious or historical reflection gets trimmed on account of Till's ecumenical approach. Similarly, the coarse, earthy aspect of Luther's writings remains absent-relating Luther's views on the human condition and justification by faith come third to portraying Luther as a defender of religious freedom and righteous reformer.

In Rome, we see the young monk, played by the handsome Joseph Fiennes-even with a monk haircut, he still has the eau de Shakespeare in Love about his person-thrust face to face with Till's representation of the corruption of the Catholic Church. A lecherous monk hiring a prostitute opens a scene of Luther, amidst the poor and the prostitutes, looking fearful and confused-at the sight of vendors selling beads and relics, he looks scared. From the start, the indulgent nature of the church is emphasized by the tender-faced Luther. In a very short time, the film tries to establish the context of Catholic waywardness and careless faith - a very obvious tactic to set Luther up as the lamb in the den of wolves, a familiar story that the film maintains until the end. Luther indeed became obsessed with his search for a merciful God and his agony over the unworthy humans who claim to believe in the righteous God. However, this nuance never quite seeps all the way through Till's characterization of Luther. Instead, at the onset, the film portrays a very feeling Luther, insecure in his every action, only to later vamp on the hagiographic theme of Luther's life and work, focusing on his bellicose lecturing, while avoiding the tumultuous core of Luther's religious journey.

Luther contains more than a few moments of displaced characterization that make the authentic German locations and storyline ring hollow; anachronisms in architecture and props undermine the power of Till's representation. As a priest in Erfurt, Luther is confronted with monks propositioning prostitutes and he is surrounded by the poor, sick, and suffering German people. Luther has a somewhat revelatory, and odd, moment when he reacts against the Catholic Church's graceless-ness after a young boy commits suicide-an emotionally effective moment, this is true, but seemingly irrelevant to the theological struggles that consumed Luther.

However, it is interesting to note, this is the only point in the film at which there is any mention of shit: distraught over the death of the boy, Luther thrashes and curses the devil saying, "I defy you devil, [you] shit. I know your handy work" and later he tells the peasants "God must be mercy" as he drops his cross into the grave of the dead boy. The devil is shit, so much that his influence not only seeps into the teachings of the church, but also the personal lives of Luther's fellow believers. The moment of struggle is high drama, but here is the only glimpse of a connection between the devil's work and the excrement of the human body—both are a part of the every day, and both, in Luther's case, can cause immense trouble.

The scene of Luther's struggle with the young boy is important for more than this fecal mention, and the incongruity of props and historical accuracy only make the scene more unusual. Luther's response to the boy's death plays upon the emotional pitch of the film, yet in Luther's time and context, such an act would never be committed by a deeply devout Augustinian monk like Luther. The focus on his sermons to his congregation and his focus on Christ "in every corner" speaks clearly the message the film wishes to convey—religious liberty, not authenticity-yet Luther retains the veneer of Joseph "Shakespeare in Love" Fiennes as some "emo" handsome Luther (Der schöne Luther) ([19], p. 61). Wipfler touches again on the implausibility of certain aspects of Luther's characterization in Till's film-there is a distinct lack of faithful conviction in the confident, swaggering college lecturer and emotional monk turned reformer.

At first, Luther groans around the Augustinian monastery as a grumpy, bellowing, anxiety-ridden neurotic monk, but after a short time serving in Erfurt, he becomes more of a confident, somewhat sarcastic professor of theology in Wittenberg. During Luther's easy, breezy instruction, he cracks jokes to his students, telling them, "For a silver florin I freed my grandfather from purgatory ... For twice that, I could have sprung Grandma and Uncle Marcus too." The students laugh, Luther seems in 
control, and perhaps all the viewer can do is smile with him, due to the dearth of historical context and a full cast of important religious thinkers and theologians. Though the film entertains and looks well, the lack of references to the religious milieu of the time means the film perseveres in feeling somewhat flat, and the comedy, if it can be called such, fails to bridge the gap between the everyday and the spiritually transcendent.

Despite Luther's confidence in his professorship, Till's fill still seems to keep Luther's humanized humor at arm's length, instead focusing on a message of religious freedom. At times, strong themes of German nationalism seem to overpower the message, and again the heavy drama becomes the main focus of the film. Overall, there appears to be very little humor in Till's rendition of Luther's teachings and early protest, and perhaps this is accurate-not until there was a more definitive and pursued break with the Roman Catholic Church did Luther fully subsume his role as mocker of the pope and the Church.

In Luther's writing "On the Councils and the Church," he writes, "but the canonists are such stupid asses and fools, with their idol in Rome, that they convert the words and deeds of the dear fathers into articles of faith against their will and without their consent" ([11], p. 558). Till's film passes over the vulgarity of Luther's statements, and unwaveringly reiterates Luther's saintly aspects. In his review of Luther, Peter Chattaway remarks that unlike earlier productions (Osborne's 1961 play), "there is practically no reference whatsoever to the crude, scatological, and vehemently anti-rationalist elements in Luther's teachings. There is, so to speak, no reference to the very earthy toilet which the historians now find so key to the man" [24]. Chattaway's reference to the archeological discovery of Luther's legendary commode, on which he allegedly wrote the "95 Theses," brings into the discussion the human side of Luther.

Till's film establishes its stance early on-emotion over the human condition—and perhaps this, in combination with the theological weaknesses, accounts for the underwhelming representation of Luther. Chattaway acknowledges that the result is "an unbalanced portrait of Luther that is at once both sympathetic and triumphalistic. He obviously has his demons, as do we all, but his cause is always right and he never says or does anything particularly scandalous." His cause is right, and his characterization is distant; whereas some of Luther's writings are polarizing, they are undeniably representative of the human conflict between holiness and sinfulness, a contrast that perhaps could have shocked Till's Luther enough to revitalize and ameliorate the "emotional thrust that occasionally dissolves into hagiographic kitsch" ([19], p. 61).

Regrettably, kitsch and sentimentality share the stage in Luther, and the real emotional struggle Luther faced does not get its share of screen time. As Stephen Holden writes in his review of the film, "When the historical details become too clogged, the movie shamelessly overcompensates by wallowing in cheap sentimentality" [25]. This is again emphasized by the rather one-sided depiction of both Luther and the Catholic Church-Luther's righteousness does not waver much throughout the film, there is not one mention of Johann Eck, and only a passing nod to Philipp Melanchthon. Many of the important figures of the time walk on screen only to keep walking straight off, and it does seem that if more time had been spared for the tensions between these characters than on painting Luther as a saint, then there would have been a flavor of the fulfilling consubstantiality of Luther's life.

Holden notes this when he writes that despite all of the emotion fed to the viewers, "the character never quite achieves a full human dimension. His marriage to a runaway nun, Katerina von Borg (Claire Cox), is cursorily handled in the stock manner of a historical soap opera" [25]. The lively ex-nun, Katy, woos Luther with a courting song, singing, "Evil tongues will mock. We will mock in turn," though we never hear the beautiful mocking for ourselves. Luther says that most days he "cannot get out of bed, I'm so depressed," and Katy brings him joyous music.

His marriage to Katy may be the strongest hint towards the human, bodily, earthily sensual side of humanity - that is, the part to which we relate. Luther's human need for a wife is in addition to his complete devotion to God, painting a more authentic portrait of a human, Christian life, a portrait that speaks more directly to the incongruity of unrighteous human and Almighty holiness. The human 
body and mortal world, after all, were given by God to be enjoyed with love and laughter, but Till seems to prefer emotional kitsch to this relatable consubstantial theology.

Despite Till's avoidance of Luther's earthy vulgarity in favor of a saintly depiction, the message of religious liberty provides fodder for the fire of discussion. In the background, the true stirrings of the reformation occur, and the film ends, after the reading of the Augsburg confession, with the words: "What happened at Augsburg confession pushed open the door of religious freedom." Though the Reformation paved a small way for religious liberty, Luther's own words sing a different song that speaks of the individual liberty that comes from believing in the power of faith and the grace of a merciful God. "For faith alone means peace of conscience," writes Luther, and living one's faith fully in this life certainly means embracing the joy, instruction, and laughter that a faithful humor provides ([15], p. 312). Though Till's film hits a few flat notes, one can see Luther's personality in fits and starts, and the overarching message of religious freedom will, one hopes, draw its viewers into a discussion of where religious liberty and modern Christian practices stand in the ever-changing world - though, we argue, a little laughter could smooth and quicken such a conversation, and ensure that we do not forget our God-given corporeality as we strive towards a more fulfilling, consubstantial spirituality.

\section{Conclusions}

Erasmus observed that "It's the generally accepted privilege of theologians to stretch the heavens, that is, the Scriptures, like tanners with a hide." If theologians stretch the Scriptures like tanners stretch a hide, how much more do filmmakers of the saints' lives stretch history to entertain spectators and propagate their favorite hobby-horses? Frequently in their passion to make a point or preach a sermon, they forget one remarkable element of human nature: laughter. Thus they often sandpaper off the wit and humor of saints in solemn attempts to capture the solemnity of their topics. They try to make saints more spiritual than God. While raunchy humor is frequently elided in the films for the sake of presenting a sanitized image of holiness, we believe it essential for two reasons. First, it offers a secondary avenue for Luther in retraining his wrath, by transferring it into wit. Secondly, satire and humor are actually quite serious rhetorical tactics and theological weapons in challenging the work of the devil. They put the fallen angel in his place, which appears to be the latrine of hell.

One does not diminish or downplay the gravity of Luther's life, but what is serious can easily be combined with what is comic. The opposite of the comic is the tragic, even as the trivial is the antonym for seriousness. It is the comedy in the life of Luther that makes him more authentic. ${ }^{14}$ In the American imagination, and in two of the films discussed, Luther stands resolutely, and so becomes heroic. It is Osborne who humanizes him by allowing his humor [22]. ${ }^{15}$ The rebellious Luther (with Keach not handsome like the Fiennes version) allows a little bit of sex and vulgarity to the soul-searching monk. As his father tells him in the film, "Martin you would like to pretend that you made yourself, that is, you who made you - and not the body of a woman and another man."

The Lutheran Reformation, as Walter Lippman once observed, was "intended only for good Catholics" ([31], p. 226). The questions raised, however, are for all men and women. Can film communicate an experience of sanctification, of the presence of God in earthen vessels? Hagiographic films have the potential to function as icons in the mode of sacrament, in the realization of the lived human condition, when they delve into the full humanity of the person. To sense the comic in a human being is to connect, to become potentially consubstantial with that person by laughing with her or him. Laughter connects, stuck between Abraham and Israel, between the promise of a Covenant and the reality of a community and nation-laughter is born and reproduces.

\footnotetext{
14 Animated versions of Luther have also appeared such as the YouTube [26] and [27] as well as a version of Horrible Histories [28] and a very comic sketch by Monty Python [29].

15 See also [30].
} 
Celluloid Saints can seem too ethereal, too aesthetic, and not carnal enough to invite a sensory encounter [32]. Embodiment comes through a full sense of incarnation, where the fuller person is communicated via the moving image. Strength is perfected in weakness and lived identification comes most frequently through the sins of the saints, not their virtues. The aesthetics of dung remind one of how far short one falls, and that even the ethical stage is insufficient to redeem oneself. There is a grace and righteousness beyond ourselves, for both Roman Catholics and Protestants.

Author Contributions: Lindvall designed the initial argument, research schedule, and identified appropriate data sources. All authors performed research in both theological and historical subjects, as well as research on the films analyzed herein. Data was analyzed and reviewed separately, combined, and analyzed again by all authors. All authors contributed to writing the paper. All authors read and approved the final manuscript.

Conflicts of Interest: The authors declare no conflict of interest.

\section{References}

1. Haile, Harry Gerald. Luther: An Experiment in Biography. Princeton: Princeton University Press, 1983.

2. Berger, Peter. Rumors of Angels: Modern Society and the Rediscovery of the Supernatural. Garden City: Anchor, 1970.

3. Burke, Kenneth. A Rhetoric of Motives. Berkeley: University of California Press, 1969.

4. Gavrilyuk, Paul L., and Sarah Coakley. The Spiritual Senses: Perceiving God in Western Christianity. Cambridge: Cambridge University Press, 2014.

5. Dyrness, William. Poetic Theology: God and the Poetics of Everyday Life. Grand Rapids: Eerdmans, 2010.

6. Gibson, Walter S. Pieter Bruegel and the Art of Laughter. Berkeley: University of California Press, 2006.

7. Lindvall, Terry. God Mocks: A History of Religion and Satire from the Hebrew Prophets to Stephen Colbert. New York: New York University Press, 2015.

8. MacCullough, Diamaid. Reformation: A History. New York: Penguin, 2005.

9. Schmidt, Josef, and Mary Simon. "Holy and Unholy Shit: The Pragmatic Context of Scatological Curses in Early German Reformation Satire." In Fecal Matters in Modern Literature and Art. Edited by Jeff Persels, and Russell Ganim. Surrey: Ashgate, 2004, pp. 109-17.

10. Gritsch, Eric W. Wit of Martin Luther. Minneapolis: Fortress, 2006.

11. Luther, Martin, and Helmut T. Lehman. "On the Councils and the Church." In Luther's Works. Edited by Eric W. Gritsch. Augsburg: Fortress Press, 1966, vol. 41.

12. Gritsch, Eric W. "Martin Luther's Humor." Word \& World 32 (2012): 21-195.

13. Gritsch, Eric W. “Luther's Humor: Instrument of Witness.” Dialog 22 (1983): 177-80.

14. Gallonio, Antonio. Life of Saint Philip Neri. San Francisco: Ignatius Press, 2006.

15. Kittelson, James M. Luther the Reformer. Minneapolis: Fortress Press, 2003.

16. Lewis, C. S. The Screwtape Letters. New York: Macmillan, 1968.

17. Lewis, C. S. Miracles. New York: Macmillan, 1947.

18. The Seventh Seal. Directed by Ingmar Bergman, Performed by Max von Sydow; Stockholm: Svensk Filmindustri, 1957, DVD.

19. Wipfler, Esther P. Martin Luther in Motion Pictures: History of a Metamorphosis. Göttingen: Vandenhoeck \& Ruprecht, 2011.

20. Martin Luther: His Life and Time. Directed by Karl Wüstenhagen, Wittenberg: Luther Film Production Company, 1923, DVD.

21. Martin Luther. Directed by Irving Pichel, Performed by Niall MacGinnis; St. Louis: De Rochemont/Lutheran Productions, 1953, DVD.

22. Osborne, John. Luther: A Play. New York: Signet, 1963.

23. Luther. Directed by Eric Till, Performed by Joseph Fiennes; Berlin: NFP Teleart, 2003, DVD.

24. Chattaway, Peter T. "Review: Luther (dir. Eric Till, 2003)." Patheos, $2004 . \quad$ Available online: http://www.patheos.com/blogs/filmchat/2004/10/review-luther-dir-eric-till-2003.html (accessed on 31 October 2015).

25. Holden, Stephen. "Film Review: Martin Luther's Passion, Still Resonating Today." The New York Times, 2003. Available online: http://www.nytimes.com/2003/09/26/movies/film-review-martin-luther-s-passionstill-resonating-today.html (accessed on 31 October 2015). 
26. Sam Mulberry. "Reformation Polka." Available online: https://www.youtube.com/watch?v=b4TeJJmQJqU) (accessed on 31 October 2015).

27. Zsolt Richly. "Luther." Available online: https://www.youtube.com/watch?v=5Kt0oaRt2uA) (accessed on 31 October 2015).

28. "Horrible Histories: Cash My Sins." Available online: https:/ /www.youtube.com/watch?v=un2qxIlqLP8 (accessed on 31 October 2015).

29. Python, Monty. "The Adventures of Martin Luther." Available online: https://www.youtube.com/ watch? $=Y$ XzubuENjHk (accessed on 31 October 2015).

30. Heston, Patrick C. "The Reformers: A History of the Reformation: Martin Luther, Selections from The Wittenburg Door" quoted in William H. Willimon. In Last Laugh. Nashville: Abingdon, 1991, pp. 40-43.

31. Zuver, Dudley. Salvation by Laughter. New York: Harper and Brothers, 1933.

32. Sanders, Theresa. Celluloid Saints: Images of Sanctity in Film. Macon: Mercer University Press, 2002.

(C) 2016 by the authors; licensee MDPI, Basel, Switzerland. This article is an open access article distributed under the terms and conditions of the Creative Commons by Attribution (CC-BY) license (http://creativecommons.org/licenses/by/4.0/). 